\title{
"Rio+20: What we can learn from the process and what is missing"
}

\author{
"Rio+20: O que podemos aprender com o processo de discussão e o que está faltando"
}

Jose A. Puppim de Oliveira ${ }^{2}$

\begin{abstract}
The United Nations Conference on Environment and Development (UNCED) took place in the city of Rio de Janeiro in 1992 and put the concept of Sustainable Development definitively on policy agendas at all levels from global to local. Twenty years later, even though important progress has been made in several areas, the world still struggles to implement the decisions following up the UNCED and to steer humanity towards a more sustainable path. The UN has set two broad themes for the Earth Summit in 2012, or Rio+20: institutional framework for sustainable development (IFSD) and green economy in the context of sustainable development and poverty eradication. This article makes an overall analysis of the discussions generated by Rio+20. The article starts with a short overview of the debates on sustainable development since the UNCED, until the recent debates on green economy and institutional frameworks for sustainable development. It then highlights some lessons from the discussions catalyzed by Rio +20 analysing why and how progress has been achieved in certain areas and what the obstacles are to move the agenda of green economy and good environmental governance forward to achieve a more sustainable development. It concludes that, besides the tremendous obstacles to implement the agenda on green economy and IFSD, these themes brought about in Rio+20 are still lacking conceptually in the discussions on important topics such as equity and need to changes in values, as well as the debates on governance beyond the international level.
\end{abstract}

Keywords: Rio+20. Green Economy. Governance. Sustainable Development

\section{Resumo}

A Conferência das Nações Unidas para o Meio Ambiente e o Desenvolvimento (CNUMAD), ou Rio-92 ou Eco-92, que aconteceu na cidade do Rio de Janeiro, colocou o conceito de Desenvolvimento Sustentável definitivamente na agenda política, em todos os níveis, do global ao local. Vinte anos depois, embora avanços importantes tenham sido feitos em várias áreas, o mundo ainda tem dificuldades para implementar a agenda da CNUMAD e direcionar a humanidade para um desenvolvimento mais sustentável. Assim, a ONU determinou dois temas como o foco da Cimeira da Terra em 2012, ou Rio+20: Arcabouço Institucional para o Desenvolvimento Sustentável (IFSD em inglês) e economia verde no contexto de desenvolvimento sustentável e erradicação da pobreza. Este artigo faz uma análise geral das discussões geradas pela Rio+20. O artigo começa com uma revisão dos debates desde a CNUMAD, incluindo as discussões recentes sobre os dois temas da Rio+20. O texto avança com uma análise dos debates da Rio+20 examinando porque e como a agenda avançou em certas áreas e quais os obstáculos para avançar a agenda da economia verde e boa governança ambiental para atingir um desenvolvimento mais sustentável. O artigo conclui que, além dos enormes obstáculos para implementar a agenda da economia verde e IFSD, existem ainda lacunas conceituais nas discussões, por exemplo

Artigo submetido em 15 de maio de 2012 e aceito para publicação em 31 de agosto de 2012.

1 This paper is a modified version of the introduction and conclusion chapters of the book edited by the author: PUPPIM DE OLIVEIRA, J.A. Green Economy and Good Governance for Sustainable Development: Opportunities, Promises and Concerns. Tokyo: United Nations University Press, 2012. The author thanks the United Nations University (UNU) Press for the license to publish parts of these chapter in this paper.

2 Ph.D. Assistant Director and Senior Research Fellow (UNU-IAS). Address: United Nations University Institute of Advanced Studies (UNU-IAS) - 6F International Organizations Center, Pacifico-Yokohama; 1-1-1 Minato Mirai, Nishi-ku / Yokohama 220-8502 Japan. E-mail: puppim@ias.unu.edu 
temas como equidade e necessidade de mudança de valores, como também o aprofundamento das discussões de governança além do plano internacional.

Palavras- chave: Rio+20. Economia Verde. Governança. Desenvolvimento Sustentável.

\section{Introduction}

The United Nations Conference on Environment and Development (UNCED) took place in the city of Rio de Janeiro in 1992 and put the concept of Sustainable Development definitively on policy agendas at all levels from global to local. It was one of the largest gatherings of world leaders and generated a series of important documents such as Agenda 21, the UN Framework Convention on Climate Change (UNFCCC), the Convention on Biological Diversity (CBD) and the United Nations Convention to Combat Desertification (UNCCD).

Almost twenty years later, even though important progress has been made in several areas, the world still struggles to implement the decisions following up the UNCED and to steer humanity towards a more sustainable path. Thus, in order to advance further the implementation of the sustainable development agenda, the UN organized a new Earth Summit in Rio in 2012, coined as Rio+20, and set two broad themes for discussions: Institutional framework for sustainable development (IFSD) and green economy in the context of sustainable development and poverty eradication (UN, 2010). The debates on these two themes will likely permeate the discussions in the sustainability arena in the near future.

The term "Sustainable Development" became popular in the 1990s particularly after the release of the Brundtland Report and the Rio-92 (UNCED) Conference. The term definitively broke the stalemate between environmental protection, economic development and social inclusiveness (called the three pillars of sustainable development), offering the possibility that all three could come together without a trade-off, at least in theory. Nevertheless, this has not always held true in practice. Even though environmental awareness has increased and there are many good examples to illustrate sustainable development around the world, the planet has become dangerously more unsustainable in several aspects, such as loss of biodiversity and climate change, which have also affected the most vulnerable populations. Thus, the question many raise is how to achieve environmental sustainability with reasonable economic growth that can lead to poverty alleviation and social inclusiveness at all levels (local, national and global). The key observation to answer this question is the difficulty of achieving sustainable development due to the lack of institutions capable of translating the concept of sustainable development into practice.

One relevant policy question is how to translate global concerns into local action, and local concerns into global action. However, we still have a long way to go. We have to create effective and democratic institutional mechanisms to make sustainable development a reality in practice at the various levels. Many of the organizations and institutions in the different levels still operate in the old paradigm of development or are unable to bring the three pillars of sustainable development together in an effective manner. They have to be changed to create the capacity to effectively move societies and the world on a more sustainable path.

Moreover, institutions at the national and sub-national level need to interact with global institutions to make societies work properly for sustainable development. Resources and knowledge have to be used effectively to address many of the global challenges. Economic institutions also have to be reformed to be greener and more socially inclusive so that they lead to poverty eradication and a more sustainable development. However, we need to understand how they can be mainstreamed and make radical changes in the way the economy and organizations work to eradicate poverty and to be environmentally sustainable. Thus, the challenges and opportunities for creating a greener economy and the institutional framework for sustainable development rest necessarily, or mostly, on how we can be effective in incorporating the challenges of sustainable development into our institutions and creating the implementation capacity to translate those concerns into practice (GLEMAREC and PUPPIM de OLIVEIRA, 2012). 


\section{Towards the Limits}

The world has faced massive changes in the last three centuries. Until the eighteenth century, humans had a limited form of energy for using in production and transportation, particularly their own energy and the energy from animals, wind and biomass. This limited human action both in intensity and scale, even though the great navigations in the East and West were the first step to globalization. However, the invention and dissemination of the steam power in large scale changed definitively the reach of human action, and consequently the world. Steam power catalysed the emerging industrial revolution and allowed humans to use the energy from abundant coal and other fossil fuels to increase their capacity to transform materials and transport goods much more efficiently.

The industrial revolution was initially a technological revolution, but led to huge transformations and consequences in the economy, society, politics and in the environment both local and global. In economic terms, the revolution improved the labour productivity and production leading to a huge increase in the material wealth of the societies. These economic changes implied a transformation of the societies both urban and rural. Factories demanded labour, bringing people to live around them, and consequently led to urbanization. They also demanded raw materials from the rural areas, such as wool, leading to a pressure to increase the production on the farms, and the final break-up of some feudal systems. In political economy, the industrial revolution consolidated market capitalism as a political system, but it also created an increasing degree of inequality in societies and led to the creation of a working class in the urban areas, which influenced political changes, such as a stronger labour movement, which in turn sparked many socialist revolutions around the world.

The possibilities from the industrial revolution expanded the capacity of humans to interfere with nature. Firstly, there was a huge increase in the use of natural resources, both to produce inputs to the industrial processes and to feed the machines with fuels. On the other hand, the new, more efficient forms of transportation enabled industries to bring inputs and reach markets far away. However, the byproducts of the increase in production, like air and water pollution, could be felt all over the big industrial cities, as well as in the less evident degradation of the ecosystems far away from the cities due to an increase in agricultural production or exploitation of natural resources.

Those rapid changes in the eighteenth and nineteenth centuries caused profound changes in the relation between humans and nature. Many societies aimed to increase their material wealth to improve their wellbeing, and indeed, society has been richer on average since the industrial revolution. "Development", which initially was synonymous with economic growth, was pursued at any cost. The social and environmental problems, such as air pollution, income inequalities and lack of sanitation in the cities, caused by rapid industrialization and urbanization were regarded as the price to be paid to "develop". In the first quarter of the twentieth century, this seemed to be the universal view, and not only in the capitalist world. In the Soviet Union, industrialization without care for environmental consequences was also the motto for their development, as portrayed in a poster from the Soviet Era, which says "the smoke from the chimneys is the Soviet Russia's breath." Environmental pollution was almost synonymous with "development" and was even something desirable. This was the economic development at any cost practiced in modern society, both in capitalist and communist regimes, in the first half of the twentieth century.

\section{The Rise of the Debates on Sustainable Development towards Rio+20}

The term sustainable development stemmed from many of the social movements in the society that asked for social and political changes, such as feminism, the civil and human rights movements, and pacifism. The evolving discussions in the environmental conservation debate brought together the different movements when the term sustainable development was coined and popularized in the 1980s. Even though, the "green" agenda is still dominant in the debates on sustainable development, this agenda was changed significantly since the voice of the other social movements joined the debates on sustainable development. Nevertheless, 
the history of the environmental movements overtime is key to understand how we reached the current discussions on sustainable development.

The conservationist movement in the United States in the nineteenth century could be considered the first "modern" environmental movement on a large scale. The American conservationists developed some of the core actions of the environmental conservation movement that exists until today, such as natural parks to protect certain natural areas from human action for the common good. They were concerned that the "expansion to the west" would cause the same consequences on nature as they did in the eastern part of the USA. The conservationist movement achieved important political landmarks, such as the creation of the first National Park (Yellowstone), and was responsible for influencing conservation policies all over the world. However, they were not enough to make radical changes in the way human action affected nature. They tried to isolate (conserve) part of nature from human action, but not changing human action, per se, which continued with the economic and industrial growth at any cost. Moreover, the turbulent first half of the twentieth century, with two world wars, socialist revolutions and economic recessions, blurred the political relevance of the continuing environmental degradation during this period.

After the Second World War, the large economic powers (the so-called "developed countries") reorganized their economies and industrial parks. Many of them propelled by high rates of economic growth soon achieved industrial production and per capita income higher than they had prior to the war. In the 1960s, their populations achieved significant levels of consumption and material wealth, which have not yet been achieved by large parts of the population in Asia, Africa and Latin America in the 2010s. Nevertheless, the high level of material wealth did not lead necessarily to other benefits in terms of quality of life. Many city inhabitants in the developed countries were living in places with high levels of air and water pollution in the $1950 \mathrm{~s}$, as the result of the expansion of industrial activities. In the rural areas, the "green revolution" (i.e., the use of modern methods for agricultural production, such as the use of machines, chemical fertilizers and pesticides) facilitated the expansion of the agricultural fields and contamination of the environment.

Intellectuals started to raise their voices alerting to the destruction of nature, such as Rachel Carlson with the book Silent Spring (CARLSON, 1962). In many cities, high levels of contamination led to many health problems with the appearance of diseases never before seen. In Japan, high levels of noxious pollutants, including heavy metals, contaminated entire populations, such as the case in Minamata or Yokkaichi (TSURU,1999; PUPPIM de OLIVEIRA, 2011).

In the conceptual field, still in the 1960s, there was a dilemma on how to combat environmental problems. The mainstream political, business and economic thought claimed that environmental pollution was the natural consequence of economic development and the price to pay for increasing material wealth. Thus, there was a supposed trade-off between economy and the environment. If a society wanted high levels of economic wealth, it had to support high levels of environmental pollution that came with new factories and cars that were the engines of economic growth. Businesses claimed that if some cities did not want the development they brought, they could move their factories to other cities or countries that were happy to accept the trade-off.

In the instrumental field, on the other hand, the State and society did not have the tools or means to make compatible economic development with environmental quality. The few tools available were to zone areas for industrial development and try to distance them from residential areas. Environmental Impact Assessment was incipient in most of the countries and still not institutionalized completely. The other alternative was to halt industrial development, or even close down factories to stop pollution. However, industries generated a large part of taxes on which the State depended, and that also provided services and jobs for the population, who might oppose any initiatives that would cut their jobs.

As neither businesses nor governments was willing to take action, environmental movements started to appear and become relevant in civil society. Initially, neighborhood associations, small environmental groups, schools, universities and labour unions protested against environmental contamination and its consequence on specific populations and on environmental issues, such as nuclear energy. They were also 
interacting with a range of other social movements that were emerging in the industrialized countries, such us feminism, pacifism and the civil rights movements. Many of the environmental movements thought in line with the conceptual mainstream ideas, that there was a trade-off between environmental protection and economic development, but they claimed that was urgent to have zero or negative economic growth in order to have a better environment. Those movements became larger both in scale and resources, and more influential in politics, and were the seeds of the transnational environmental movements we have today.

At the international level, there were rising concerns as well. The report from the Club of Rome in 1972 (MEADOWS et al., 1972), comprising respected specialists, showed through modeling techniques that the increasing population and use of natural resources would strain the planet. The report had a large impact on policymakers internationally, and was translated into several languages. Nevertheless, the economyenvironment trade-off was still the only major conceptual framework to consider the solutions to the environmental crisis.

The growing environmental concerns, protests and reports in the beginning of the 1970s led to the organization of the United Nations Conference on the Human Environment in Stockholm, Sweden, in 1972. It had the heavy industrial pollution in developed countries as its main concern, led by an emerging environmental movement in those countries influenced by the conceptual framework of the trade-off between environment and economic development. The agenda was driven by the developed countries, which had suffered from heavy industrial pollution and internal political pressure from environmentalists. Developing countries had different views on the environmental issues at that time. Some countries, like India, expressed their concern that environmental problems may be caused by poverty and the lack of economic opportunities. Others were skeptical about the intentions behind the environmental concerns and the zero economic growth theories that many proposed as a solution. They saw the international environmental movements as attempts to block developing countries from opportunities to develop their economies; many of these developing countries had rapid growth rates and were already showing signs of the same environmental problems as the developed countries. The Stockholm conference was fundamental to institutionalize the environmental debate in the global agenda and in the national policies of many countries, which started to create their state institutions to cope with environmental concerns. It also led to the creation of the United Nations Environmental Programme (UNEP). Nevertheless, the debates did not include issues like inequality, poverty and other dimensions coming from the different social movements, which were important particularly to developing countries. The debates were shaped mostly by "Western" concerns and ideas.

During the 1970s and 1980s, the environmental agenda expanded to a large number of countries that created national and sub-national laws and organizations to control environmental problems. Nevertheless, the mainstream idea of the existence of the economy-environment trade-off was questioned. On the one hand, there were a lot of win-win situations between environmental protection and economic gains, as many improvements in environmental management reduced waste and led to improvements in economic efficiency, for example, in some industrial processes, the so called eco-efficiency. Moreover, tighter environmental standards in developed countries, such as car emissions, did not reduce the demand for cars or jobs in the automobile industry in the 1970s. On the other hand, lack of economic development, and not excess of positive economic growth, was indeed the root of some of the environmental problems, such as lack of sanitation or deforestation in some developing countries. The mainstream framework to combat environmental degradation was also lacking important dimensions, such as economic and development inequalities and poverty.

The continuing depletion of natural resources and the environment pollution in some countries and its consequences for economic and social development led the United Nations to create the World Commission on Environment and Development (WCED) or Brundtland Commission, chaired by Gro Harlem Brundtland (former Norwegian prime-minister) in 1983. The Commission released its report in 1987, widely known as Our Common Future or Brundtland Report, which popularized the concept of sustainable development and had a huge impact on international and national policies all over the world (WCED, 1987). The concept of development was already being questioned for its narrow focus on economic development, and the idea of 
the Human Development Index was being developed by UNDP (UNDP, 1990). The report from WCED consolidated the framework that economic and social development can go hand in hand with environmental protection. It was also important to include the needs of future generations as part of the development equation. The Commission defined sustainable development as one that "meets the needs of the present without compromising the ability of future generations to meet their own needs." The environmental and development agenda post-WCED was changed definitively. It moved from being only "green" to trying to make environmental protection compatible with social and economic development for the present and future generations. This matches the evolution of the environmental movements both in developed, but particularly in developing countries, such as Brazil (VIOLA, 1992), where social and economic issues have greater relevance in the policy agendas.

While the WCED met and presented its results, the existence of new environmental problems emerged, such as the depletion of the ozone layer, biodiversity loss and global warming. The nature of these problems was different from that of previous problems related to local air and water pollution, as they had global causes and consequences and needed global solutions. One country alone could not solve these problems.

The need to find the solution for global problems and search for a new kind of development, or sustainable development, brought the UN to call for the second large global environmental summit, the UN Conference of the Environment and Development (UNCED), or Rio-92, in Rio de Janeiro, Brazil, in 1992. The conference produced important conventions and other documents such as Agenda 21, the Convention on Biological Diversity (CBD) and the UN Framework Convention on Climate Change (UNFCCC). Agenda 21, a blueprint for the implementation of sustainable development, was widely discussed around the world, and thousands of Agendas 21 were drafted at the national, sub-national and local level.

Rio-92 was also a landmark conference in terms of participation and governance. The conference convened the largest number of heads of states or governments up until then. The civil society, particularly environmental groups, was also widely represented at the conference and some held their own parallel meetings in the Global Forum organized by NGOs. Some business leaders also joined the conference eagerly and proposed solutions to sustainable development (SCHMIDHEINY, 1992). Civil society groups had a large influence on the discussions during Rio-92 and consolidated their participation in the official environmental meetings. The socalled Major Groups are now part of almost all environment and development discussions. On the other hand, international organizations and many governments realized that solutions and the policies to tackle environmental problems could only be implemented with the engagement of civil society, both businesses and environmental NGOs. The conference also brought non-environmental groups of interest to the table, such as non-environmental NGOs and social movements, development organizations and business.

One of the most important contributions of Rio-92 was the launch of a positive agenda that seemed possible. There was a new concept of development (sustainable development) on which all agreed as a basis. Many important documents and international laws were supported by almost all countries, laying out the blueprint of a set of international norms that could solve many of the global and local environmental problems. The large involvement of the civil society signaled a new, more participative governance structure indicating the broad support governments would receive in making the necessary changes to pursue sustainable development. The UN Commission for Sustainable Development (UNCSD) was created to follow-up the decisions of Rio-92. Rio-92 changed the environmental discourse and politics forever. Environmental movements became more concerned about social and economic aspects and non-environmental organizations gained more awareness of environmental issues.

After Rio-92, the concept of sustainable development became popular in government policies, business projects and political discourses. Agenda 21 was discussed and drafted in many places at the different levels around the world. Several interesting projects at the local and regional scale that could achieve environmental protection with economic and social benefits came up. This included the apparent control of the global menaces of the $1980 \mathrm{~s}$, such as the destruction of the ozone layer, by controlling the emission of the most important Ozone Depleting Substances (ODS). The Rio conventions achieved important breakthroughs in follow-up international agreements, such as the Cartagena and Kyoto protocols. 
In 2000, the UN and the world leaders launched the Millennium Development Goals (MDGs) at the UN Millennium Summit, setting a series of goals to mitigate some of the major social and environmental problems around the world. Nevertheless, when government leaders and civil society met again in Johannesburg, South Africa, in the Earth Summit (or Rio+10) in 2002, they concluded that the environmental and social situation in many aspects was worse than it was 10 years earlier, and sustainable development was not being achieved in developed or in developing countries, even though there was an improvement in awareness and the institutional capacity to deal with sustainable development. Johannesburg and the MDGs also brought poverty and human development to the centre of the debate on sustainable development. Poverty was framed more strongly as a global problem that also needed global solutions. Developed countries promised more resources for international development. The main output of the meeting was the Johannesburg Plan of Implementation, in which the parties committed themselves to achieve the MDGs and implement Agenda 21 and the international agreements.

\section{Rio+20: Green Economy and Governance for Sustainable Development}

Twenty years after Rio-92, the same old problems, such as deforestation, air and water pollution, persist in many parts of the world and many global problems have been aggravated, including climate change and biodiversity loss. New problems have emerged, such as the degradation of the oceans and the increasing concentration of Persistent Organic Pollutants (POPs). The agenda for sustainable development is more complex as the population keeps growing and the economic crises hit several parts of the world. Many of the problems are intertwined and win-win solutions are not always easy. Even when there is commitment, there are implementation gaps in the capacity of international regimes and governments to make changes happen on the ground on a large scale.

Under this context, the United Nations set two main topics of discussions for United Nations Conference on Sustainable Development (UNCSD) or Rio+20 and beyond: Institutional Frameworks for Sustainable Development and Green Economy in the Context of Sustainable Development and Poverty Eradication (UN, 2010). There was the belief that addressing these topics could lead to a more sustainable development.

\section{Green Economy: Old Ideas with New Labels}

The concept of green economy is not new. The discussions on how to value the environment and include environmental economic values in markets and in governmental policies have been around for more than three decades, most notably the "polluter pays principle" of the 1970s. There is solid literature on environmental and ecological economics, as well as green debates in political economy (PEARCE, 1976; CONSTANZA, 1991). Many methods and tools have been developed to assess and introduce environmental values in economic and financial decisions at diverse levels, such as the Stern Review (STERN, 2006) and the recent The Economics of Ecosystems and Biodiversity - TEEB Report (TEEB, 2010). Many initiatives of green taxes or accounting have been introduced in public policies at the local, national and global level, such as the Clean Development Mechanism (CDM) of the Kyoto Protocol. The debates have evolved to other dimensions as trade with the announcement of green economy as a theme for Rio+20 (UNCTAD, 2010; UNEP/UNCTAD, 2010).

However, green economy has been the target of several criticisms. It has not been mainstreamed into the main economy. Its effects have not been enough to stop the continued environmental degradation. In addition, many criticize that green economy has benefited large corporations and the rich, not the poor, as well as not emphasizing the discussions on inequalities. It has not been framed to work for the poor. Thus, the concept of green economy set by UNEP (2011a) now includes "in the context of sustainable development and poverty alleviation". However, reaching a consensus on these topics is not an easy task, such as Green Economy itself, which has been very controversial. For example, the expression generated heated debate and alienated some countries that asked to be left out of the declaration during the Latin American and Caribbean 
Regional Preparatory Meeting for Rio $+20 .^{3}$ In the discussions on the institutional frameworks for sustainable development, the idea of the creation of a global environmental agency is also very polemical with no consensus or agreement.

\section{The institutional framework for sustainable development (IFSD): The missing gap}

The institutional framework for sustainable development (IFSD) is the other main discussion theme set by the UN. At the global level, there have been several long term research efforts and seminal works published on the global governance mechanisms trying to understand the effectiveness of international environmental regimes (KALLHAUGE, SJÖSTEDT and CORELL, 2005; SELIN, 2010; OBERTHUR and STOKKE, 2011; YOUNG, KING and SCHROEDER, 2008; YOUNG, 1999; 2010). Emergent patterns of environmental governance at the global level have consolidated, but we still need to understand how they emerge and how to assess their effectiveness. However, the debates of the IFSD have focused mostly on reforms of international organizations, including the UN (UNEP, 2010; BERNSTEIN and BRUNNÉ, 2011). Even though the discussions of the reforms and the multilateral regimes and laws are relevant, they are not sufficient to make all necessary changes on the ground.

The governance discussions have to include debates beyond the reform of international organizations and regimes. The work of Elinor Ostrom is an important landmark for understanding good governance of the environment and natural resources (OSTROM, 1990). Ostrom and others challenged the previous assumptions of the "tragedy of the commons", which described the destruction of common managed resources (HARDIN, 1968). Ostrom showed that there were many cases around the world where good governance of "common pool resources" exist. Those resources were managed by local communities, which created the institutions (e.g., rules and enforcement mechanisms) that led to good governance in the use of the resources in the long term. Even though her theoretical work still has some limitations in terms of the assumed rationality of the social actors, she showed that common pool resources can be managed collectively and the tragedy of the commons can be avoided.

Ostrom also studied the challenges concerning the management of large-scale resources, such as marine ecosystems, and identified that "[i]nstitutional diversity may be as important as biological diversity for our long-term survival" (OSTROM et al., 1999). However, there is little understanding of this diversity of institutions and how they lead to patterns of good governance that cut across scales (local to global) in different environments. We still need to understand the diversity of institutions that can lead to good governance of environmental resources at the different levels, connecting governance and socio-ecological outcomes, and also connecting all the previous research that have been undertaken at the local, governmental and global level in order to provide policy-relevant research outcomes to guide practices in the area.

\section{Key issues and lessons learned from the discussion in the Rio+20 process}

The Rio +20 conference is now past. Even though it did not come up with important outputs, such as new conventions or treaties, it left a legacy of two years of debates in academia and practice on the two main themes. Thus, this section analyses the main lessons from the discussions related to the topics of Rio+20. It also points out some of the shortcomings in the economic and political institutions hindering the creation of a greener economy that boosts environmentally sustainable development and fights poverty. This part highlights the importance of addressing these shortcomings from different perspectives to advance a more integrated approach to a greener economy and governance.

${ }^{3}$ Conclusions of the Latin American and Caribbean Regional Meeting Preparatory to the United Nations Conference on Sustainable Development. 


\section{There are trade-offs in the green economy}

Even though the concept of the green economy is not new, experiences up to now have generally been on an ad hoc basis and lacking in scale. For example, we still do not have one application of the green economy at the country or regional level that simultaneously covers several sectors. The case of payments for ecosystem services to mitigate deforestation in Costa Rica is one of the few examples at a larger scale (the country level), but it is still limited to the forestry sector. Moreover, some of the large-scale examples, such as ethanol in Brazil, initially had different objectives than that of sustainable development or poverty alleviation (PUPPIM de OLIVEIRA, 2002).

The recent interest in bringing the green economy back to policy discussions at the highest level with a focus on poverty alleviation could lead to new experiments in practice. However, there are several potential obstacles to the implementation of green economy initiatives. For example, when analysing experiences in three southern African countries, Resnick, Thurlow and Tarp (2012) argue that green growth is difficult to achieve in those countries because general socioeconomic objectives, such as job creation and poverty alleviation, may clash with environmental sustainability. There is no straightforward way of pulling off a win-win situation that achieves economic growth, poverty alleviation and environmental protection at the same time. The authors claim that, as with many other economic reforms, the reforms needed to promote green growth require short-term sacrifices to achieve long-term objectives and may face tremendous opposition from some groups, including the poor.

It is still difficult in most cases to integrate the different objectives of a green economy with one another. Measuring economic outcomes and linking them to social and environmental aspects is not an easy task, and efforts have been made to provide new systems to report economic and social progress that presents this reality (STIGLITZ et al., 2009). In practice, there are significant trade-offs that prevent the green economy from becoming a reality in many situations for both rich and poor countries at present. Aligning diverse objectives and short-term interests with long-term goals, such as poverty alleviation and climate change mitigation, may be possible on a small scale or in certain conditions or localities. However, any large-scale cross-cutting initiatives will probably face enormous implementation challenges and may require tremendous financial and technical efforts, as well as strong political support at the national and international levels. Gaining such backing does not seem feasible in the short term, especially in the present global financial situation and with the current governance structures at the various levels. Moreover, in order to create a greener economy, an institutional framework needs to be in place to regulate the economy, but most of today's economy is unregulated, remaining informal or beyond the control of existing mechanisms like a large part of international financial systems. Thus, the green economy probably needs to be preceded by a larger reform in the economic institutions and regulatory organizations.

\section{The political economy may prevent change}

The local political economy presents another set of obstacles in implementing sustainable development policies. Achieving a greener economy involves huge distributional implications from the economic and social costs and benefits at all levels. In aggregate, society is expected to accrue significant economic, social and environmental benefits in the medium and long term with a green economy. However, some will lose a lot in order to allow others to gain a little. Some of the losers from the green economy are politically influential and are likely to put a lot of political pressure on various stakeholders to prevent or change green economy policies.

For example, reducing climate change by the rate necessary to avoid a collapse in the many of the Earth's supporting systems entails an enormous shift from our dependence on fossil fuels towards the use of renewable energies. This, in turn, will leave potential winners and losers. However, if renewables become an alternative, oil-producing countries may lose their major - and in some cases only - source of hard currency, which is used to finance basic public services. Many of these countries, such as Nigeria and Angola, are still poor and may be big losers if financial mechanisms are not put in place to ease the transition. A change to renewables without any compensation may also spur resistance in the oil companies, which are some of the 
largest corporations in the world and have a lot of political clout. Mining and energy corporations may resist the various low-carbon green growth policies in southern African countries, because those policies go against the corporations' interests (RESNICK et al, 2012). Financing the implementation of alternative mechanisms has faced difficulties, as in the Ecuadorian proposal for compensation in exchange for leaving the oil reserves in the Yasuni National Park unexploited to protect its rainforest, biodiversity and inhabitants. Largescale schemes, such as REDD+, may also need significant amounts of resources that may not be readily available. Identifying those trade-offs at the global, national and local levels would help to make explicit what obstacles would be likely to appear and what needs to be done to move the green economy and sustainability agenda forward in a particular context.

\section{Equity concerns are still not at the centre of discussions on the green economy}

Environmental quality is closely linked to human well-being, as the Millennium Ecosystem Assessment (MA, 2005) demonstrated in the case of ecosystem services. However, neither the costs nor the benefits related to the environment are distributed evenly: some individuals, groups and countries are affected differently by changes in the environment. There are important equity implications when we discuss the health of the environment or the gains from environmental improvement. Climate change is a good example of how unevenly the causes and consequences of the changes in climate are distributed. Even though we are all responsible for the problem (through the principle of "common but differentiated responsibilities"), the richest are those who have polluted most, but the poorest are more likely to suffer from the harshest consequences because they are generally more vulnerable and lack the resources to adapt quickly.

Discussions on the green economy tend to consider the idea of economic growth as the main outcome, with little emphasis on equity aspects, even though the outcomes of decisions and development processes have important equity implications. Thus, if more sustainable, fairer development is the long-term objective of development processes around the world, equity should be brought to the centre of discussions on the green economy and the institutional framework for sustainable development.

Understanding how development processes has an impact on equity and how to change governance to have fairer outcomes for the most vulnerable and powerless groups in several arenas is an issue to be solved. The well-being of several disadvantaged societal groups, communities and regions around the world is threatened by environmental degradation for which they are not directly responsible. For example, in terms of biodiversity, new mechanisms to improve the governance of biological resources could have a positive impact on the most vulnerable communities that depend on those resources. Overconsumption to heat the economy in some parts of the world, sometimes in the same locality, leads to negative impacts in other parts, generally where the most vulnerable groups work or live, such as the poor or indigenous peoples. Those groups are also generally powerless to make the necessary changes in resource governance to change the course of actions.

\section{Discussions on technology need to be broadened beyond the "technological fix"}

Unlike in the 1950s and 1960s, when stresses on our environment started to become a social and political concern, technical knowledge and technological solutions are today much more advanced. In the past, the implementation of solutions was hindered because basic technical knowledge and tools were not available. For example, when the problem of Minamata disease emerged in Japan in the 1950s, the health effects of mercury and other heavy metals were mostly unknown. Today, we have a huge amount of information about those effects and the technology to tackle such problems. In the 1960s, we also did not have the basic technologies for effective desulphurization and denitrification of air pollutants, which are widespread today.

Technology is readily available to provide sustainable solutions in many situations. For example, technology could untap the tremendous potential of geothermal energy in many countries. Geothermal energy could be an affordable source of sustainable energy for many people who do not have access to basic energy supplies, thus improving social conditions in many parts of the world. Many developing countries, such as El Salvador and Kenya, have started to exploit this potential. A greater effort to develop technical capacity in some 
developing countries could also have a significant impact on the production of clean energy, and consequently on the social improvements needed to achieve the Millennium Development Goals.

However, many of the solutions for sustainability problems lie in the economic, social and political viability of the technological solutions that are widely available today. Moreover, the availability of technologies and their distribution became the main driver to find solutions to unsustainability problems. In the context of a green economy, this has ethical foundations and equity implications (MATHAI and PARAYIL, 2012). There are gaps in the proposed "green technological revolution" aimed at providing a "technological fix" for sustainability problems. There is a lack of understanding of the value of sufficiency to complement efficiency in discussions on the green economy. Most of the technological solutions are based solely on the optimization of economic efficiency, which has equity implications because the efficiency gains are not distributed evenly.

Another set of discussions concerns access to technological development and the sharing of its benefits. Many technological developments are based on natural assets in different parts of the globe. How these benefits are or should be shared is directly or indirectly addressed is still an unsolved issue. Biodiversity can bring huge benefits to society, including the potential for new technologies to produce new pharmaceutical products and cosmetics. Even though the Nagoya Protocol on Access and Benefit-sharing provides a framework for improving the equity aspects of bio-prospecting, there are still governance gaps. For example, one of the most untapped resources on Earth in terms of knowledge is the oceans. Oceans are also one of the least regulated resources in terms of access, both to manage the resources per se (for example, fisheries) and the knowledge based on those resources. Bio-prospecting in the sea has developed rapidly, but there is a gap in the governance of both the benefits from the resources and the risks.

\section{Good governance with governments, but beyond international organizations and national governments}

Most of the discussions on what is called the institutional framework for sustainable development are focused on global governance, especially the reform of the United Nations system. Reforms are needed in the international governance system to produce more efficient, fairer outcomes from international environmental processes. These discussions emphasize the role of international organizations and national governments, and, to a lesser extent, non-governmental actors, in the governance mechanisms. Even though these discussions are important for strengthening the international system, because the national governments are legitimate representatives of the people living within their borders, many other actors have been active in influencing governance at various levels. However, complexity in the governance of many issues may require a broader set of actors than those commonly explored by the traditional governance literature, particularly if we want to strengthen the link to implementation.

Important stakeholders in several policy processes on diverse issues at different scales are still not influential, such as the role of indigenous peoples in global environmental governance (McLEAN et al., 2012). They are present in several countries around the world and have contributed to many global processes, but their views are still not represented by many national governments. Strengthening their role and their "traditional" knowledge could make a rich contribution to international discussions as well as to innovations in implementation. Local authorities and subnational governments are another set of actors whose involvement in global governance has grown (PUPPIM de OLIVEIRA, 2009). Cities, where most of the world's population lives, have a huge potential to tackle global environmental issues, particularly climate change. The governance of cities will determine the future of the green economy because cities are the backbone of the economy of most countries and their influence goes well beyond their boundaries.

\section{The importance of values and traditional knowledge systems is not fully recognized}

The transition to a more sustainable society will need a radical change in the values of mainstream society: West and East, North and South. This implies a change in the ways we think and do things in all aspects of our personal and professional lives. Different knowledge systems need to emerge and transform "Western"style society. On the one hand, some "Western" values have contributed a lot to making the world better, for 
example by stressing the importance of freedom and the rule of law and even by allowing the emergence of ecological concerns and the idea of sustainable development. Western science was a key factor in identifying the limits of the planet and warning of climate change and destruction of the ozone layer. However, other aspects of Western values were responsible for leading us towards unsustainable lifestyles and poorly regulated systems for governing the Earth's natural resources, both locally and globally.

It is important to bring different sets of values from society in order to make changes towards a more sustainable development path. Education could be a tool in transforming the unsustainable production and consumption patterns in modern societies. This would be a necessary condition for achieving the objectives of the green economy. Education for sustainable development would need to be incorporated into the existing educational structures, focusing the learning process on values compatible with sustainable development, such as equity and justice, and local sustainable innovation. Certain of these new values are embedded in some traditional knowledge systems. Many traditional societies produce and consume in a much more sustainable way and have maintained a close link with nature for many generations. At the international level, indigenous groups with their traditional knowledge systems have added new knowledge and values to the global environmental processes, but they still need to be strengthened in these processes and supported at the local and regional levels because some of them are under threat. Agricultural systems that use natural resources in a sustainable manner could provide an alternative to the large-scale agricultural systems that are dependent on many external inputs. In another example, socio-ecological production landscapes are under threat owing to the loss of traditional knowledge and socioeconomic transformations such as rural-urban emigration or population ageing. They claim that an international effort to revive those traditional knowledge systems could provide an alternative mechanism to boost a greener economy.

\section{Innovation capacity needs to be at the centre of the search for the sustainable solutions}

Discourses on limits push for a stronger political commitment by countries, major groups and international organizations to develop a credible institutional framework for guiding us to more sustainable development and steering the mainstream economy to a greener path that could eradicate poverty. However, we need more innovation capacity to generate the tools and mechanisms to transform broad concepts into practical results for advancing the implementation of such commitments. It is necessary to stress the importance of putting innovation, both technical and non-technical, at the centre of the debates on the green economy and governance.

The experience and the capacity of societies to innovate locally is essential to generate viable solutions to local and global problems. Two main points related to this should be highlighted from the previous discussions. The first point is to create mechanisms to identify and generate innovative solutions, both technological and institutional, that can have large positive impacts on societies. Those innovations have to cut across sectors and regions and lead to radical impacts on the way societies use environmental resources and distribute their benefits. Incremental small changes towards sustainable development are still important, but it is only with more radical changes that we can achieve the proposed international goals, such as reductions in greenhouse gas emissions or the preservation of biodiversity, in order to avoid future unsustainable paths. Thus, in addition to the effective implementation of individual projects and programmes, innovative initiatives with a much larger impact are necessary.

The second point is to create governance mechanisms that facilitate the dynamic exchange of knowledge and resources locally and globally to generate and diffuse the innovative solutions needed for radical changes. We have to create mechanisms that facilitate the development of local innovation capacities in order to scale up innovations. Because many of the solutions to global concerns emerge at the local level, we need local and global efforts to create the capacity to innovate locally and spread those innovations globally to those who need them. Local groups must be able to adopt the best technologies for their local needs, absorb new technologies and create the institutional mechanisms to increase their benefits. Thus, we need to understand the global mechanisms that facilitate the diffusion of knowledge and resources to enable the development and dissemination of good local solutions to other localities in a fair, effective and efficient manner. An international forum or agency on sustainable innovation that could coordinate efforts to govern, promote, 
identify and diffuse sustainable innovations, both technological and institutional, would be essential to accelerate the implementation of the sustainable development agenda.

\section{Final remarks}

The Earth is under pressure and needs dramatic changes in the way we use and abuse its carrying capacity. Unlike the report of the Club of Rome (MEADOWS et al., 1972), which forewarned of environmental ramifications in decades ahead, this time some tipping points have already been reached, as in the case of climate change, which may have irreversible consequences. Apart from the population almost doubling in the last 40 years, the level of consumption of many natural resources has increased several fold (UNEP, 2011a). Yet, even with such large increases, many of the pressing social problems in many countries, such as poverty, continue to indicate an unequal utilization of resources. Another difference from the 1970s is our access to knowledge about the sustainability problems we face today. We know much more about local and global environmental problems and their consequences today than we knew in the 1970s, when environmentrelated sciences were emerging and the links between environmental, social and economic issues were still mostly unknown. We also lacked the tools and technology we have today. Nevertheless, we have not been able to create governance mechanisms, at either the global or the national level, to make the necessary changes to steer our societies and economies towards a more sustainable path. Even though governance over our environmental resources has evolved and decision processes linked to sustainable development issues have been more participatory and transparent in some aspects, we have not reached the point of making the radical changes we need.

In this context, the discussions on the green economy and the institutional framework for sustainable development are timely. There is an urgent need to decouple the economy from the use of natural resources (UNEP, 2011b), so that economic growth will not pile more stress on our limited resources. Moreover, besides being greener, the economy should help to solve pressing social problems such as poverty. We also need appropriate institutions and organizational structures at the international level to be more efficient, transparent and effective in making decisions and implementing them. As pointed out earlier, these discussions are not new in practice or in the literature.

Even though recent discussions have benefited from the accumulation of empirical and theoretical knowledge in past decades, they have not produced the kind of conceptual originality and tools necessary to put the green economy on the mainstream political, social and economic agenda. Much of past and present discussions on the green economy are based on the mainstream market-based economic system and the values that are embedded in it. This system was responsible for creating the problems in the first place, and it is unlikely to be the solution. There are huge gaps between intentions and results when the green economy is put into practice.

There is also a lack of discussions on important topics such as equity and changes in values. On the other hand, discussions on governance remain mostly in the international sphere; discussions at the national and subnational level are unconvincing, but they are also a key factor in implementation, such as the governance of oceans or the role of indigenous peoples.

The way economies function and political organizations respond determines how sustainable we are at the local, national and global levels. Reforming economic and political institutions is indeed a necessary condition if we want to move towards a more sustainable world, in which we maintain our environment and eradicate many of our social problems, such as poverty. We know a lot about the green economy and governance, but there is a lack of political will to move the agenda forward, which may also depend on larger reforms in economic and political systems. We also lack the tools to carry out changes. However, emerging new discussions on the green economy and governance offer some positive signs that changes may be possible. Nevertheless, a "golden bullet" that would automatically solve all problems is unlikely to exist. We 
need to discuss and analyse specific issues in depth to come up with solutions that are politically legitimate, socially acceptable and economically viable.

\section{References}

BERNSTEIN S.; BRUNNÉ, J. Options for Broader Reform of the Institutional Framework for Sustainable Development (IFSD): Structural, Legal, and Financial Aspects, 2011. Report prepared for the Secretariat of the United Nations Conference on Sustainable Development (Rio+20), UNECA. Available at http://www.uneca.org/eca_programmes/sdd/events/Rio20/cfssd7/IFSD\%20FIVE\%20OPTIONS\%20REPORT_31Oct11 .pdf (Accessed 10 January 2012).

CARLSON, R. Silent Spring. Boston, Houghton Mifflin, 1962.

CONSTANZA, R. Ecological Economics, the Science and Management of Sustainability. New York, Columbia University Press, 1991.

GLEMAREC, Y.; PUPPIM DE OLIVEIRA, J.A. The role of the visible hand of public institutions in creating a sustainable future. Public Administration and Development, v. 32, n. 3, p. 200-214, 2012.

HARDIN, G. The Tragedy of the Commons. Science, v. 162, n. 3859, p.1243-1248, 1968.

KAllhauge, A.C.; SJÖSTEDT, G.; CORELL, E. (eds.) Global Challenges: Furthering the Multilateral Process for Sustainable Development. London (UK): Greenleaf Publishing, 2005.

MA (Millennium Ecosystem Assessment). Millennium Ecosystem Assessment, $2005<$ http://www.maweb.org/> (accessed 9 February 2012).

MATHAI, M.; PARAYIL, G. Towards equity and sustainability in the "green economy". In: PUPPIM DE OLIVEIRA, J. A. (Ed.). Green Economy and Good Governance for Sustainable Development: Opportunities, Promises and

Concerns. Tokyo: United Nations University Press, 2012. p. 47-70

MCLEAN, K.G.; JOHNSTON, S.; RAMOS CASTILLO, A. The Role of Indigenous Peoples in Global Environmental Governance: Looking Through the Lens of Climate Change. In: PUPPIM DE OLIVEIRA, J. A. (Ed.). Green Economy and Good Governance for Sustainable Development: Opportunities, Promises and Concerns. Tokyo: United Nations University Press, 2012. p. 245-266.

MEADOWS, D.L.; MEADOWS, D.H.; RANDERS, J.; BEHRENS, W. W. The Limits to Growth. New York, Universe Books, 1972.

OBERTHUR, S.; STOKKE, O.S. (eds.). Managing Institutional Complexity: Regime Interplay and Global Environmental Change, Cambridge (USA), MIT Press, 2011.

OSTROM, E. Governing the Commons: The Evolution of Institutions for Collective Action, Cambridge (UK), Cambridge University Press, 1990.

. ; BURGER, J.; FIELD, C.B.; NORGAARD, R.B.; POLICANSKY, D. Revisiting the Commons: Local Lessons, Global Challenges. Science, v. 284, n. 5412, p. 278-282, 1999.

PEARCE, D.W. Environmental Economics. London (UK): Longman, 1976.

PUPPIM DE OLIVEIRA, J.A. The Policymaking Process for Creating Competitive Assets for the Use of Biomass Energy: the Brazilian Alcohol Programme. Renewable \& Sustainable Energy Reviews, v. 6, nos.1-2, p. 127-138, 2002.

. The implementation of climate change related policies at the subnational level: An analysis of three countries. Habitat International, v. 33, n. 3, p. 253-259, 2009. 
Why an air pollution achiever lags on climate policy? The case of local policy implementation in Mie, Japan. Environment \& Planning A, v. 43, n. 8, p. 1894-1909, 2011.

;; O. BALABAN, C.N.H. DOLL, R. MORENO-PEÑARANDA, R.; GASPARATOS, A.; IOSSIFOVA, D. and SUWA, A. Cities, Biodiversity and Governance: Perspectives and Governance Challenges for the Convention on Biological Diversity at the City Level. Biological Conservation, v. 144, n. 5, p. 1302-1313, 2011.

Green Economy and Good Governance for Sustainable Development: Opportunities, Promises and Concerns. Tokyo: United Nations University Press, 2012.

RESNICK, D.; THURLOW, J. and TARP, F. The Political Economy of Green Growth: Cases from Southern Africa. Public Administration and Development, v. 32, n. 3, 215-228, 2012.

SCHIMIDHEINY, S. Changing course: A global business perspective on development and the environment. Cambridge (USA): MIT Press, 1992.

SELIN, H. Global Governance of Hazardous Chemicals: Challenges of Multilevel Management. Cambridge (USA): MIT Press, 2010.

STERN, N. Stern Review on The Economics of Climate Change. London (UK): HM Treasury, 2006.

STIGLITZ, J. E.; SEN, A. and FITOUSSI, J-P. Report by the Commission on the Measurement of Economic Performance and Social Progress, $2009<$ http://www.stiglitz-sen-fitoussi.fr/en/index.htm> (accessed 9 February 2012).

TEEB - The Economics of Ecosystems and Biodiversity, 2010. Available at www.teebweb.org (accessed 20 October 2011).

TSURU, S. The political economy of the environment : the case of Japan. London: Athlone Press, 1999.

UNITED NATIONS - UN. Objective and themes of the United Nations Conference on Sustainable Development (A/CONF.216/PC/7), Report of the UN Secretary-General, 2010.

UNITED NATIONS COMMISSION ON TRADE AND DEVELOPMENT (UNCTAD). The Green Economy: Trade and Sustainable Development Implications. Geneva: UNCTAD, 2010.

UNITED NATIONS DEVELOPMENT PROGRAMME (UNDP) (1990). Human Development Report. New York: UNDP, 1990.

UNITED NATIONS ENVIRONMENT PROGRAMME (UNEP)/United Nations Commission on Trade and Development (UNCTAD). The Transition to a Green Economy: Benefits, Challenges and Risks from a Sustainable Development Perspective. Geneva, UNEP/UNCTAD, 2010.

UNITED NATIONS ENVIRONMENT PROGRAMME (UNEP). "Elaboration of Ideas for Broader Reform of International Environmental Governance", Second meeting of the Consultative Group of Ministers or High-level Representatives on International Environmental Governance, Helsinki, 21-23 November, 2010 (UNEP/CGIEG.2/2/2), 2010a.

Decoupling Natural Resource Use and Environmental Impacts from Economic Growth, A Report of the Working Group on Decoupling to the International Resource Panel. Fischer-Kowalski, M., Swilling, M., von Weizsäcker, E. U., Ren, Y., Moriguchi, Y., Crane, W., Krausmann, F., Eisenmenger, N., Giljum, S., Hennicke, P., Romero Lankao, P., Siriban Manalang, A., Sewerin, S..,2010b Available at $<$ http://www.unep.org/resourcepanel/Publications/Decoupling/tabid/56048/Default.aspx> (accessed 27 July 2012).

Towards a Green Economy: Pathways to Sustainable Development and Poverty Eradication. A Synthesis for Policy Makers. Nairobi: UNEP, 2011a. 
VIOLA, E. O movimento ambientalista no Brasil (1971-1991): da denúncia e conscientização pública para a institucionalização e o desenvolvimento sustentável. In: Goldenberg, M. (Org.). Ecologia, Ciência e Política. Rio de Janeiro: Revan, 1992. p. 49-75.

WORLD COMMISSION ON ENVIRONMENT AND DEVELOPMENT (WCED) Our Common Future. New York: Oxford University Press, 1987.

YOUNG, O.R. (ed.) The effectiveness of international environmental regimes: causal connections and behavioral mechanisms. Cambridge (USA), MIT Press, 1999.

.; KING, L. A.; SCHROEDER, H. (eds.). Institutions and Environmental Challenges: Principal Findings, Applications, and Research Frontiers. Cambridge (USA): MIT Press, 2008.

Institutional Dynamics: Emergent Patterns in International Environmental Governance. Cambridge (USA): MIT Press, 2010. 